\title{
In Vitro Propagation and Determination of Total Phenolic Compounds, Flavonoid Contents and Antioxidative Activity of Globba globulifera Gagnep.
}

\author{
Wipa Yaowachai ${ }^{1,3}$, Surapon Saensouk ${ }^{2,3}$, Piyaporn Saensouk ${ }^{1,3, *}$
}

Wipa Yaowachai ${ }^{1,3}$, Surapon

Saensouk $k^{2,3}$, Piyaporn

Saensouk ${ }^{1,3, *}$

'Department of Biology, Faculty of Science, Mahasarakham University, Mahasarakham, THAILAND.

${ }^{2}$ WalaiRukhavej Botanical Research Institute, Mahasarakham University, Mahasarakham, THAILAND.

${ }^{3}$ Plant and Invertebrate Taxonomic and its Application Research Unit, Mahasarakham University, Mahasarakham, THAILAND.

\section{Correspondence}

\section{Piyaporn Saensouk}

Department of Biology, Faculty of Science: Plant and Invertebrate Taxonomic and its Application Research Unit, Mahasarakham University, Mahasarakham, THAILAND.

E-mail: pcornukaempferia@yahoo.com History

- Submission Date: 12-08-2020;

- Review completed: 25-09-2020;

- Accepted Date: 01-10-2020.

DOI : 10.5530/pj.2020.12.236

Article Available online

http://www.phcogj.com/v12/i6s

\section{Copyright}

(C) 2020 Phcogi.Com. This is an openaccess article distributed under the terms of the Creative Commons Attribution 4.0 International license.

\begin{abstract}
Introduction: Currently, there is a reduction in the number of Globba globulifera, which is due to its slow multiplication rate, high susceptibility to pathogenic diseases and overexploitation of the plant from natural sources. In vitro culture to study suitable concentrations of plant growth regulators for shoot and root induction of G. globulifera. Bioactive compounds were measured by TPC, TFC and FRSA methods for comparison of those from in vitro and natural conditions. Methods: Microshoots were cultured on solid and liquid MS medium supplemented with various concentrations of cytokinins (BA, Kinetin and TDZ) and auxins (NAA and IBA) for eight weeks. Methanol was used as the extraction solvent via the ultrasonic method, TPC and TFC were both measured. DPPH for free radical scavenging activity was investigated. Results: The best result for shoot formation was achieved when culturing on MS medium with $3 \mathrm{mg} / \mathrm{l}$ and $5 \mathrm{mg} / \mathrm{l}$ of BAP or $5 \mathrm{mg} / \mathrm{l}$ of BAP plus $1 \mathrm{mg} / \mathrm{l}$ of IBA. The plantlets were transplanted to pots in a greenhouse. All the planting material showed a $100 \%$ survival rate. The rhizomes of in vitroderived plantlets showed the highest value of TPC (52.28 mg GAE/g crude extract) and FRSA $(93.55 \%)$ and lowest of $\mathrm{IC}_{50}(0.46 \mathrm{mg} / \mathrm{ml})$. Conclusion: The in vitro culture and antioxidant activity analysis could be the foundation for plant propagation in large quantities and the use of medicine.
\end{abstract}

Key words: Bioactive compound, DPPH, Micropropagation, TFC, TPC, Zingiberaceae.

\section{INTRODUCTION}

The genus Globba is the third most diverse of herbaceous plants in the tribe Globbeae, family Zingiberaceae. Globba is distributed in tropical regions of Asia, including across all regions of Thailand. The floral structure of the plants in the genus Globba is like a dancing woman, so it is commonly known as dancing lady ginger. Many species in the genus Globba are used economically, such as G. schomburgkii and G. adhaerens, which are used as ornamental plants and for export. Some species are used as herbs, such as the roots of $G$. leucantha and G. patens that are boiled for use by women after childbirth. Moreover, an extract from the leaves of G. marantina is used as eye drops to treat conjunctivitis and eye inflammation. The essential oil of $G$. winitii can inhibit the bacteria Staphylococcus aureus, Proteus mirabilis and Micrococcus luteus. ${ }^{1}$

Globba globulifera is a herbaceous plant in the genus Globba with a height of $30-50 \mathrm{~cm}$. The inflorescences have dark purple petal-like structures, which are called bracts, with yellow and small flowers. Therefore, it is used as an ornamental plant. The rhizomes and leaves contain essential oils. The flowering occurs from May to September, and dormancy in the winter. G. globulifera is propagated by rhizomes, seeds and bulbil, which have a relatively low propagation rate. Only a few research reports in pharmaceutical on G. globulifera have been found. G. globulifera is currently threatened by natural and human disasters, deforestation, road making and smuggling for use as ornamental plants and trade. As a result, the number of plants in nature is reducing and are inadequate for exploitation by human beings. Therefore, conservation, preservation of plant genetics and plant breeding are important for the economy. Plant tissue culture techniques are used to propagate G. globulifera in vitro to increase the number of plants. Plants are sterile and can propagate throughout the year without restrictions on the season. As a guideline for using G. globulifera for medicinal herb purposes, the rhizomes, leaves, stems and root storage parts of G. globulifera can be cultured in vitro and grown under natural conditions for antioxidant extraction. The total phenolic contents, the total flavonoid contents and the free radical scavenging activity (FRSA) are measured to provide essential details for the therapeutic use of this herb.

\section{MATERIALS AND METHODS}

\section{In vitro shoot regeneration}

\section{Surface-sterilization procedures and initial culture establishment}

The bulbils of G. globulifera from plants growing under a natural environment were collected from Udon Thani Province, Thailand. The bulbils were washed for 30 min under running tap water, soaked for $1 \mathrm{~min}$ in $70 \%(\mathrm{v} / \mathrm{v})$ ethanol, followed by 
disinfection with $20 \%$ and $15 \%$ sodium hypochlorite $(\mathrm{NaOCl})$ for 20 min and 15 min under aseptic conditions, respectively. Then, rinsed in sterilized distilled water three times for 5 min. Initially, the bulbils were grown on MS medium (Murashige and Skoog) ${ }^{2}$ supplement with a combination of $2.0 \mathrm{mg} / \mathrm{l}$ BAP with $1.0 \mathrm{mg} / \mathrm{l} \mathrm{NAA}$.

\section{Shoot multiplication}

The shoot explants were transferred to solid MS medium supplemented with various concentrations of plant growth regulators. The plant growth regulators were $\operatorname{BAP}(0,1.0,2.0,3.0,4.0$ and $5.0 \mathrm{mg} / \mathrm{l})$, Kinetin $(0,1.0,2.0,3.0,4.0$ and $5.0 \mathrm{mg} / \mathrm{l}), \operatorname{BAP}(1.0,2.0,3.0,4.0$ and $5.0 \mathrm{mg} / \mathrm{l})$ in combination with NAA $(0.5$ and $1 \mathrm{mg} / \mathrm{l})$, BAP $(1.0,2.0,3.0,4.0$ and $5.0 \mathrm{mg} / \mathrm{l})$ in combination with IBA $(0.5$ and $1 \mathrm{mg} / \mathrm{l})$, Kinetin $(1.0$, 2.0, 3.0, 4.0 and $5.0 \mathrm{mg} / \mathrm{l})$ in combination with NAA $(0.5$ and $1 \mathrm{mg} / \mathrm{l})$ and Kinetin (1.0, 2.0, 3.0, 4.0 and $5.0 \mathrm{mg} / \mathrm{l})$ in combination with IBA $(0.5$ and $1 \mathrm{mg} / \mathrm{l})$. The MS liquid medium supplemented with $3.0 \mathrm{mg} / \mathrm{l}$ of Kinetin in combination with $0.5 \mathrm{mg} / \mathrm{l}$ of NAA (Parida et al. $)^{3}, 2.0$ $\mathrm{mg} / \mathrm{l}$ of BAP (Chuengpanya et al.) ${ }^{4}$ and $2.0 \mathrm{mg} / \mathrm{l}$ of TDZ (Saensouk et al. $)^{5}$ was used for the culture media. The explants were cultured on liquid and solid (7 g/l of bacto agar) MS media to study the effect of the type of media. For all media, the $\mathrm{pH}$ was modified to 5.7-5.8 and the media was autoclaved at $121^{\circ} \mathrm{C}$ for $15 \mathrm{~min}$, with 10 replications for each procedure. Mean number of shoots, mean length of shoot $(\mathrm{cm})$, mean number of roots and mean length of root $(\mathrm{cm})$ per explant were measured. Cultures were incubated with fluorescent lamps at $25 \pm 2{ }^{\circ} \mathrm{C}$ under a $16 \mathrm{~h}$ photoperiod for eight weeks.

\section{Acclimatization}

The plantlet was kept at room temperature for four weeks and then after culturing in the MS medium for another eight weeks. The plantlets had shoots and roots that were well established, and they were $6-8 \mathrm{~cm}$ in height. Then the plantlets were removed from the glass bottle. The roots were gently washed in running tap water to remove the crop media debris and transferred to the greenhouse for eight weeks in plastic pots containing soil, sand and soil mixed with sand $(1: 1 \mathrm{w} / \mathrm{w})$. The survival rate, mean number of shoots, mean length of shoot $(\mathrm{cm})$, mean number of leaves, mean length of leaf $(\mathrm{cm})$ and mean width of leaf $(\mathrm{cm})$ per plantlet were measured for eight weeks.

\section{Bioactive Compounds}

\section{Plant material}

In vitro-derived plantlets for one year and those derived from natural conditions were used as the plant material. The parts of $G$. globulifera used in the study were the rhizomes, root storage, leaves and pseudostems. Healthy plants were selected, wash thoroughly with running tap water and cut into small pieces. The pieces of G. globulifera were first frozen for 12 hours at $-80{ }^{\circ} \mathrm{C}$, and then quickly put into a freeze dryer. Ground thoroughly with a herb grinder, and then the specimens were stored in a desiccant jar.

\section{Antioxidant extraction}

Antioxidant extraction was according to the procedure described by An et al. ${ }^{6}$ with modifications. For this, $5 \mathrm{~g}$ of G. globulifera explant powder was precisely weighed, then added to $30 \mathrm{ml} 80 \%$ methanol. Each different explant was extracted ultrasonically for $30 \mathrm{~min}$ three times and filtered. The methanol was removed in a freeze dryer through drying. The extraction procedure was repeated three times. The sample solution was prepared from the crude extract. For this, $1 \mathrm{mg}$ of the crude extract was added into the microcentrifuge tube, and then $1 \mathrm{ml}$ of $80 \%$ methanol was added and mixed with a vortex $(1 \mathrm{mg} / \mathrm{ml}$ stock solution).

\section{Determination of total phenolic contents (TPC)}

The total phenolic contents in the extracts was determined using the Folin-Ciocalteu assay as describe by Lister et al. ${ }^{7}$ with modification. Samples $(100 \mu \mathrm{l})$ were added to a microcentrifuge tube that contained $500 \mu \mathrm{l}$ of $10 \%(\mathrm{v} / \mathrm{v})$ Folin-Ciocalteu phenol reagents. They were mixed and incubated in a dark place for $1 \mathrm{~min}$. Then a solution of $400 \mu \mathrm{l}$ of $7.5 \%$ $(\mathrm{w} / \mathrm{v})$ sodium carbonate was added to the mixture, and then placed in the dark for $30 \mathrm{~min}$. Then $80 \%(\mathrm{v} / \mathrm{v})$ methanol was used as a blank. The absorbance was measured at $765 \mathrm{~nm}$ using a spectrophotometer. Gallic acid (3-100 mg/l) was used as a standard. The total phenolic content was expressed as mg gallic acid equivalent per gram of crude extract (mg GAE/g crude extract).

\section{Determination of total flavonoid contents (TFC)}

TFC in the extract was determined using the Aluminium trichloride method as describe by Zhishen et al. ${ }^{8}$ with modification. Initially, $50 \mu \mathrm{l}$ of each sample was added to a microcentrifuge tube. Then $30 \mu \mathrm{l}$ of $5 \%$ $(\mathrm{w} / \mathrm{v}) \mathrm{NaNO}_{2}$ was added to the mixture, and after $6 \mathrm{~min}$ it was placed in the dark, $60 \mu \mathrm{l}$ of $10 \%(\mathrm{w} / \mathrm{v}) \mathrm{AlCl}_{3}$ was added. After $6 \mathrm{~min}$ in the dark, and $300 \mu \mathrm{l}$ of $1 \mathrm{M} \mathrm{NaOH}$ was added. Following this, $560 \mu \mathrm{l}$ of deionize water was added to the reaction and mixed well. Then $80 \%$ (v/v) methanol was used as a blank. The absorbance was measured at $510 \mathrm{~nm}$ using a spectrophotometer. Catechin (3-200 mg/l) was used as the standard. TFC was expressed as $\mathrm{mg}$ catechin equivalent per gram of crude extract (mg CE/g crude extract).

\section{Determination of DPPH radical scavenging assay}

2,2-Diphenyl-1-picrylhydrazyl (DPPH), which is stable, was used to determine the free radical scavenging capacity as described by Yen and $\mathrm{Hsieh}^{9}$ with modification. For this, $335 \mu \mathrm{l}$ of a range of dilutions of the extracts $(0.05-1 \mathrm{mg} / \mathrm{ml})$ was added to $665 \mu \mathrm{l}$ of $0.2 \mathrm{mM} \mathrm{DPPH}$ solution in methanol and mixed well, and after this it was incubated at room temperature in the dark for $30 \mathrm{~min}$. The absorbance was measured at $510 \mathrm{~nm}$ using a spectrophotometer. The absorbance was used to calculate the free radical scavenging activity (FRSA, \%) with the equation: \%FRSA $=\left[\left(\mathrm{A}_{\text {Blank }}-\mathrm{A}_{\text {Sample }}\right) / \mathrm{A}_{\text {Blank }}\right] \times 100$. The half maximal inhibitory concentration $\left(\mathrm{IC}_{50}\right)$ was determined from the plotted graph of \%FRSA and scavenging activity against the concentration of the sample extracts. The scavenging ability of the antioxidants by the $\mathrm{IC}_{50}$ value of each sample was compared with the $\mathrm{IC}_{50}$ values of ascorbic acid.

\section{Statistical analysis}

The experiments were conducted using a completely randomized design (CRD). Data were analyzed for significance using ANOVA and differences were contrasted using a Duncan's multiple range test $(p<0.05)$ with the SPSS program version 15.

\section{RESULTS}

\section{In vitro shoot regeneration}

Microshoots of G. globulifera (1 cm length) were cultured on MS solid medium for eight weeks with various concentrations of a plant growth regulator for shoot and root formation. The highest number of shoots was obtained on the medium supplemented with $3 \mathrm{mg} / \mathrm{l}$ and $5 \mathrm{mg} / \mathrm{l}$ of BAP (4.40 shoots/explant). The best shoot length was observed on 3 $\mathrm{mg} / \mathrm{l}$ of BAP $(2.67 \mathrm{~cm})$. The highest average number of roots per shoot and the best root length were observed in $5 \mathrm{mg} / \mathrm{l}$ and $4 \mathrm{mg} / \mathrm{l}$ of BAP, respectively $(24.20$ roots/explant and $1.67 \mathrm{~cm}$ ) (Table 1 and Figure 1). The MS medium containing $5 \mathrm{mg} / \mathrm{l}$ of Kinetin showed the highest number of shoots ( 4.80 shoots/explant), shoot length $(2.42 \mathrm{~cm})$, average number of roots (23.20 roots/explant) and root length $(2.26 \mathrm{~cm})$ (Table 2 and Figure 1). 
Yaowachai, et al.: In Vitro Propagation and Determination of Total Phenolic Compounds, Flavonoid Contents and Antioxidative Activity of Globba globulifera Gagnep.

Table 1: Effect of BAP on shoot and root multiplication of G. globulifera for eight weeks.

\begin{tabular}{|c|c|c|c|c|}
\hline $\begin{array}{c}\text { BAP } \\
(\mathrm{mg} / \mathrm{l})\end{array}$ & $\begin{array}{l}\text { Average no. of } \\
\text { shoots/explant } \\
\text { mean } \pm \text { SE }\end{array}$ & $\begin{array}{c}\text { Average shoot } \\
\text { length }(\mathrm{cm}) \\
\text { mean } \pm \mathrm{SE}\end{array}$ & $\begin{array}{c}\text { Average no. of } \\
\text { roots/explant } \\
\text { mean } \pm S E\end{array}$ & $\begin{array}{c}\text { Average root } \\
\text { length }(\mathrm{cm}) \\
\text { mean } \pm \mathrm{SE}\end{array}$ \\
\hline 0 & $2.60 \pm 0.22^{c}$ & $1.07 \pm 0.06^{\mathrm{e}}$ & $11.90 \pm 1.14^{\mathrm{d}}$ & $0.69 \pm 0.04^{\mathrm{d}}$ \\
\hline 1 & $3.10 \pm 0.23^{b c}$ & $1.36 \pm 0.03^{\mathrm{d}}$ & $13.20 \pm 0.55^{\mathrm{d}}$ & $1.20 \pm 0.04^{\mathrm{c}}$ \\
\hline 2 & $3.50 \pm 0.27^{\mathrm{b}}$ & $1.52 \pm 0.05^{\mathrm{d}}$ & $20.00 \pm 0.49^{c}$ & $1.21 \pm 0.02^{c}$ \\
\hline 3 & $4.40 \pm 0.22^{\mathrm{a}}$ & $2.67 \pm 0.10^{\mathrm{a}}$ & $21.20 \pm 0.79^{b c}$ & $1.33 \pm 0.05^{c}$ \\
\hline 4 & $4.10 \pm 0.28^{\mathrm{ab}}$ & $2.10 \pm 0.06^{c}$ & $22.80 \pm 0.59^{\mathrm{ab}}$ & $1.67 \pm 0.03^{\mathrm{a}}$ \\
\hline 5 & $4.40 \pm 0.31^{\mathrm{a}}$ & $2.38 \pm 0.09^{b}$ & $24.20 \pm 0.53^{\mathrm{a}}$ & $1.50 \pm 0.07^{\mathrm{b}}$ \\
\hline
\end{tabular}

Means followed by same letters within each column are not significantly different at $p \leq 0.05$, according to DMRT

Table 2: Effect of Kinetin on shoot and root multiplication of G. globulifera for eight weeks.

\begin{tabular}{|c|c|c|c|c|}
\hline $\begin{array}{l}\text { Kinetin } \\
\text { (mg/l) }\end{array}$ & $\begin{array}{c}\text { Average no. of } \\
\text { shoots/explant } \\
\text { mean } \pm S E\end{array}$ & $\begin{array}{c}\text { Average shoot } \\
\text { length }(\mathrm{cm}) \\
\text { mean } \pm \mathrm{SE}\end{array}$ & $\begin{array}{c}\text { Average no. of } \\
\text { roots/explant } \\
\text { mean } \pm S E\end{array}$ & $\begin{array}{c}\text { Average root } \\
\text { length }(\mathrm{cm}) \\
\text { mean } \pm S E\end{array}$ \\
\hline 0 & $2.60 \pm 0.22^{c}$ & $1.07 \pm 0.06^{c}$ & $11.90 \pm 1.14^{c}$ & $0.69 \pm 0.04^{\mathrm{d}}$ \\
\hline 1 & $2.80 \pm 0.25^{c}$ & $2.11 \pm 0.15^{c}$ & $19.60 \pm 0.50^{\mathrm{b}}$ & $1.52 \pm 0.11^{\mathrm{c}}$ \\
\hline 2 & $3.80 \pm 0.25^{\mathrm{b}}$ & $1.96 \pm 0.09^{c}$ & $18.70 \pm 0.67^{b}$ & $1.77 \pm 0.12^{\mathrm{bc}}$ \\
\hline 3 & $3.90 \pm 0.28^{\mathrm{b}}$ & $1.95 \pm 0.05^{\mathrm{c}}$ & $21.30 \pm 0.73^{\mathrm{ab}}$ & $1.42 \pm 0.06^{c}$ \\
\hline 4 & $3.80 \pm 0.29^{b}$ & $2.23 \pm 0.13^{\mathrm{ab}}$ & $22.70 \pm 0.67^{\mathrm{a}}$ & $1.95 \pm 0.07^{\mathrm{b}}$ \\
\hline 5 & $4.80 \pm 0.29^{\mathrm{a}}$ & $2.42 \pm 0.09^{\mathrm{a}}$ & $23.20 \pm 0.79^{a}$ & $2.26 \pm 0.09^{\mathrm{a}}$ \\
\hline
\end{tabular}

Means followed by same letters within each column are not significantly different at $p \leq 0.05$, according to DMRT.

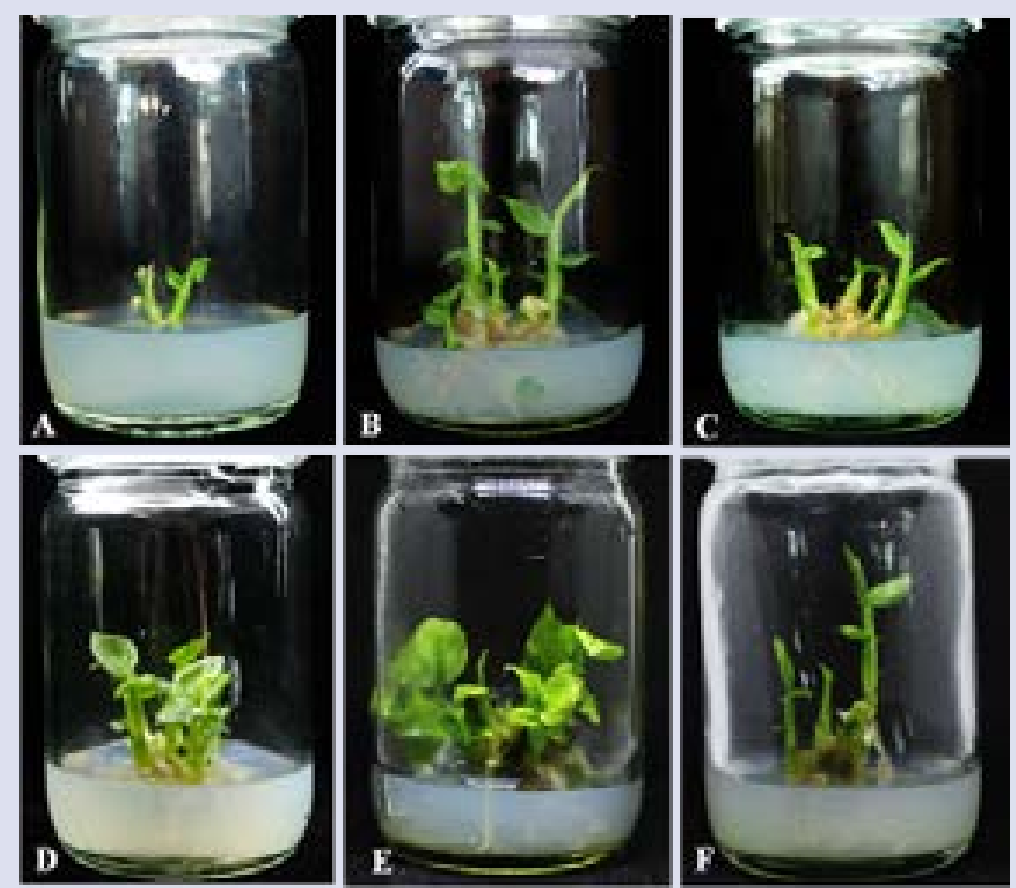

Figure 1: Multiple shoot formation of G. globulifera after eight weeks of cultivation on MS medium supplemented with plant growth regulators. (A. MS (control), B. BAP 3 $\mathrm{mg} / \mathrm{l}, \mathrm{C}$. BAP $5 \mathrm{mg} / \mathrm{l}, \mathrm{D}$. Kinetin $5 \mathrm{mg} / \mathrm{l}$, E. BAP $5 \mathrm{mg} / \mathrm{l}+\mathrm{IBA} 1 \mathrm{mg} / \mathrm{l}$ and F. Kinetin $5 \mathrm{mg} / \mathrm{l}$ $+\mathrm{NAA} 1 \mathrm{mg} / \mathrm{l})$.

The effect of a combination of cytokinins (BA and Kinetin) and auxins (NAA and IBA) showed well-developed shoot and root formation. MS medium supplemented with BAP combination with NAA or IBA had suitable shoot and root multiplication. The highest number of shoots was observed on the medium containing $5 \mathrm{mg} / \mathrm{l}$ of BAP plus $1 \mathrm{mg} / \mathrm{l}$ of IBA (6.40 shoots/explant) and the best shoot length was found on medium supplemented with $4 \mathrm{mg} / \mathrm{l}$ of BAP plus $0.5 \mathrm{mg} / \mathrm{l}$ of NAA $(2.68$ $\mathrm{cm})$. The highest average number of roots and the best root length was observed in $2 \mathrm{mg} / \mathrm{l}$ of BAP plus $0.5 \mathrm{mg} / \mathrm{l}$ of IBA (34.50 roots/explant) and $5 \mathrm{mg} / \mathrm{l}$ of BAP plus $0.5 \mathrm{mg} / \mathrm{l}$ of NAA $(1.99 \mathrm{~cm})$, respectively (Table $3)$. The MS medium supplement with $5 \mathrm{mg} / \mathrm{l}$ of Kinetin in combination with $1 \mathrm{mg} / \mathrm{l}$ of NAA showed the highest number of shoots $(6.50$ shoots/explant), shoot length $(3.20 \mathrm{~cm})$ and average number of roots (46.50 roots/explant) (Table 4 ). There were statistically significant differences when comparing the different plant growth regulators on liquid media. The liquid MS medium supplemented with $2.00 \mathrm{mg} / \mathrm{l}$ of TDZ show the highest number of shoots (12.25 shoots/explant) (Table 5 and Figure 2). 
Yaowachai, et al.: In Vitro Propagation and Determination of Total Phenolic Compounds, Flavonoid Contents and Antioxidative Activity of Globba globulifera Gagnep.

Table 3: Effect of combination with BAP plus NAA and BAP plus IBA on shoot and root multiplication of G. globulifera for eight weeks.

\begin{tabular}{|c|c|c|c|c|c|c|}
\hline $\begin{array}{c}\text { BAP } \\
(\mathrm{mg} / \mathrm{l})\end{array}$ & $\begin{array}{c}\text { NAA } \\
(\mathrm{mg} / \mathrm{l})\end{array}$ & $\begin{array}{c}\text { IBA } \\
(\mathrm{mg} / \mathrm{l})\end{array}$ & $\begin{array}{c}\text { Average no. of } \\
\text { shoots/explant } \\
\text { mean } \pm \mathrm{SE}\end{array}$ & $\begin{array}{c}\text { Average shoot } \\
\text { length }(\mathrm{cm}) \\
\text { mean } \pm \text { SE }\end{array}$ & $\begin{array}{c}\text { Average no. of } \\
\text { roots/explant } \\
\text { mean } \pm S E\end{array}$ & $\begin{array}{c}\text { Average root } \\
\text { length }(\mathrm{cm}) \\
\text { mean } \pm \mathrm{SE} \\
\end{array}$ \\
\hline 0 & 0 & 0 & $2.60 \pm 0.22^{\mathrm{e}}$ & $1.07 \pm 0.06^{\mathrm{f}}$ & $11.90 \pm 1.14^{\mathrm{e}}$ & $0.69 \pm 0.04^{\mathrm{g}}$ \\
\hline 1 & 0.5 & 0 & $4.60 \pm 0.27^{\mathrm{bcd}}$ & $2.09 \pm 0.11^{\mathrm{bc}}$ & $22.60 \pm 1.61^{\mathrm{bcd}}$ & $1.87 \pm 0.17^{\mathrm{ab}}$ \\
\hline 2 & 0.5 & 0 & $4.00 \pm 0.42^{\mathrm{cd}}$ & $2.12 \pm 0.15^{\mathrm{bc}}$ & $21.50 \pm 2.83^{\mathrm{bcd}}$ & $1.68 \pm 0.13^{\mathrm{abcd}}$ \\
\hline 3 & 0.5 & 0 & $4.70 \pm 0.40^{\mathrm{bcd}}$ & $1.96 \pm 0.12^{\text {bcde }}$ & $20.70 \pm 1.96^{\mathrm{bcd}}$ & $1.72 \pm 0.12^{\mathrm{abcd}}$ \\
\hline 4 & 0.5 & 0 & $5.00 \pm 0.26^{\mathrm{abcd}}$ & $2.68 \pm 0.21^{\mathrm{a}}$ & $24.00 \pm 2.17^{\mathrm{bcd}}$ & $1.92 \pm 0.11^{\mathrm{a}}$ \\
\hline 5 & 0.5 & 0 & $4.40 \pm 0.27^{\mathrm{bcd}}$ & $2.25 \pm 0.17^{\mathrm{ab}}$ & $23.00 \pm 1.53^{\mathrm{bcd}}$ & $1.99 \pm 0.13^{\mathrm{a}}$ \\
\hline 1 & 1 & 0 & $5.90 \pm 0.31^{\mathrm{ab}}$ & $2.38 \pm 0.22^{\mathrm{ab}}$ & $27.70 \pm 1.69^{\mathrm{ab}}$ & $1.97 \pm 0.15^{\mathrm{a}}$ \\
\hline 2 & 1 & 0 & $4.80 \pm 0.47^{\mathrm{bcd}}$ & $2.34 \pm 0.23^{\mathrm{ab}}$ & $29.20 \pm 1.87^{\mathrm{ab}}$ & $1.82 \pm 0.16^{\mathrm{abc}}$ \\
\hline 3 & 1 & 0 & $4.10 \pm 0.31^{\mathrm{cd}}$ & $2.28 \pm 0.25^{\mathrm{ab}}$ & $24.90 \pm 2.48^{\mathrm{bcd}}$ & $1.92 \pm 0.25^{\mathrm{a}}$ \\
\hline 4 & 1 & 0 & $4.70 \pm 0.15^{\mathrm{bcd}}$ & $1.84 \pm 0.11^{\mathrm{bcde}}$ & $23.50 \pm 2.21^{\mathrm{bcd}}$ & $1.40 \pm 0.09^{\text {bcdef }}$ \\
\hline 5 & 1 & 0 & $4.40 \pm 0.43^{\mathrm{bcd}}$ & $1.67 \pm 0.10^{\text {cde }}$ & $17.60 \pm 3.19^{\mathrm{de}}$ & $1.38 \pm 0.21^{\text {bcdef }}$ \\
\hline 1 & 0 & 0.5 & $4.30 \pm 0.42^{\mathrm{cd}}$ & $1.68 \pm 0.14^{\text {cde }}$ & $29.50 \pm 2.80^{\mathrm{ab}}$ & $1.10 \pm 0.05^{\mathrm{fg}}$ \\
\hline 2 & 0 & 0.5 & $4.60 \pm 0.50^{\mathrm{bcd}}$ & $1.87 \pm 0.15^{\text {bcde }}$ & $34.50 \pm 2.65^{\mathrm{a}}$ & $1.53 \pm 0.18^{\mathrm{abcdef}}$ \\
\hline 3 & 0 & 0.5 & $4.80 \pm 0.73^{\mathrm{bcd}}$ & $2.04 \pm 0.24^{\mathrm{bcd}}$ & $33.70 \pm 6.65^{\mathrm{a}}$ & $1.56 \pm 0.20^{\mathrm{abcdef}}$ \\
\hline 4 & 0 & 0.5 & $4.50 \pm 0.34^{\mathrm{bcd}}$ & $1.70 \pm 0.13^{\text {cde }}$ & $18.50 \pm 1.98^{\text {cde }}$ & $1.35 \pm 0.12^{\text {cdef }}$ \\
\hline 5 & 0 & 0.5 & $5.00 \pm 0.21^{\mathrm{abcd}}$ & $1.69 \pm 0.09^{\text {cde }}$ & $22.90 \pm 0.86^{\mathrm{bcd}}$ & $1.37 \pm 0.04^{\text {cdef }}$ \\
\hline 1 & 0 & 1 & $3.80 \pm 0.49^{\text {cde }}$ & $1.60 \pm 0.11^{\text {cde }}$ & $26.80 \pm 2.57^{\mathrm{abc}}$ & $1.62 \pm 0.27^{\mathrm{abcde}}$ \\
\hline 2 & 0 & 1 & $3.60 \pm 0.37^{\mathrm{de}}$ & $1.51 \pm 0.17^{\mathrm{def}}$ & $21.90 \pm 2.01^{\mathrm{bcd}}$ & $1.17 \pm 0.09^{\mathrm{ef}}$ \\
\hline 3 & 0 & 1 & $5.20 \pm 0.77^{\mathrm{abc}}$ & $1.43 \pm 0.11^{\mathrm{ef}}$ & $21.40 \pm 3.39^{\mathrm{bcd}}$ & $1.22 \pm 0.07^{\text {def }}$ \\
\hline 4 & 0 & 1 & $5.90 \pm 0.64^{\mathrm{ab}}$ & $1.60 \pm 0.13^{\text {cde }}$ & $25.10 \pm 2.76^{\mathrm{bcd}}$ & $1.33 \pm 0.18^{\text {cdef }}$ \\
\hline 5 & 0 & 1 & $6.40 \pm 0.70^{\mathrm{a}}$ & $2.05 \pm 0.26^{\mathrm{bcd}}$ & $26.00 \pm 2.45^{\mathrm{abcd}}$ & $1.35 \pm 0.09^{\text {cdef }}$ \\
\hline
\end{tabular}

Means followed by same letters within each column are not significantly different at $p \leq 0.05$, according to DMRT.

Table 4: Effect of combination with Kinetin plus NAA and Kinetin plus IBA on shoot and root multiplication of G. globulifera for eight weeks.

\begin{tabular}{|c|c|c|c|c|c|c|}
\hline $\begin{array}{l}\text { Kinetin } \\
(\mathrm{mg} / \mathrm{l})\end{array}$ & $\begin{array}{c}\text { NAA } \\
(\mathrm{mg} / \mathrm{l})\end{array}$ & $\begin{array}{c}\text { IBA } \\
(\mathrm{mg} / \mathrm{l})\end{array}$ & $\begin{array}{c}\text { Average no. of } \\
\text { shoots/explant } \\
\text { mean } \pm \text { SE }\end{array}$ & $\begin{array}{c}\text { Average shoot } \\
\text { length }(\mathrm{cm}) \\
\text { mean } \pm \mathrm{SE}\end{array}$ & $\begin{array}{c}\text { Average no. of } \\
\text { roots/explant } \\
\text { mean } \pm \text { SE }\end{array}$ & $\begin{array}{c}\text { Average root } \\
\text { length }(\mathrm{cm}) \\
\text { mean } \pm \text { SE } \\
\end{array}$ \\
\hline 0 & 0 & 0 & $2.60 \pm 0.22^{\mathrm{h}}$ & $1.07 \pm 0.06^{\mathrm{g}}$ & $11.90 \pm 1.14^{j}$ & $0.69 \pm 0.04^{j}$ \\
\hline 1 & 0.5 & 0 & $5.40 \pm 0.52^{\mathrm{abcd}}$ & $1.95 \pm 0.14^{\text {def }}$ & $28.40 \pm 1.19^{\text {defgh }}$ & $1.88 \pm 0.11^{\text {cde }}$ \\
\hline 2 & 0.5 & 0 & $4.70 \pm 0.37^{\text {bcdefg }}$ & $2.60 \pm 0.21^{\mathrm{abcd}}$ & $31.90 \pm 4.10^{\text {bcdef }}$ & $2.13 \pm 0.15^{b c}$ \\
\hline 3 & 0.5 & 0 & $4.60 \pm 0.31^{\text {bcdefg }}$ & $2.73 \pm 0.38^{\mathrm{abc}}$ & $32.20 \pm 3.30^{\text {bcdef }}$ & $2.32 \pm 0.19^{\mathrm{ab}}$ \\
\hline 4 & 0.5 & 0 & $5.20 \pm 0.65^{\mathrm{abcde}}$ & $3.01 \pm 0.26^{\mathrm{ab}}$ & $36.80 \pm 3.64^{\mathrm{bcde}}$ & $2.50 \pm 0.14^{\mathrm{a}}$ \\
\hline 5 & 0.5 & 0 & $5.70 \pm 0.60^{\mathrm{ab}}$ & $2.98 \pm 0.27^{\mathrm{ab}}$ & $38.60 \pm 3.59^{\mathrm{abc}}$ & $2.49 \pm 0.19^{a}$ \\
\hline 1 & 1 & 0 & $4.00 \pm 0.30^{\text {defg }}$ & $2.66 \pm 0.27^{\mathrm{abcd}}$ & $32.70 \pm 4.35^{\text {bcdef }}$ & $1.96 \pm 0.18^{\mathrm{cd}}$ \\
\hline 2 & 1 & 0 & $4.50 \pm 0.22^{\text {bcdefg }}$ & $3.00 \pm 0.35^{\mathrm{ab}}$ & $40.20 \pm 3.22^{\mathrm{ab}}$ & $1.97 \pm 0.11^{\mathrm{cd}}$ \\
\hline 3 & 1 & 0 & $4.30 \pm 0.21^{\text {bcdefg }}$ & $2.56 \pm 0.21^{\mathrm{abcd}}$ & $33.00 \pm 2.82^{\text {bcdef }}$ & $1.83 \pm 0.06^{\text {cdef }}$ \\
\hline 4 & 1 & 0 & $5.50 \pm 0.37^{\mathrm{abc}}$ & $2.83 \pm 0.31^{\mathrm{abc}}$ & $37.90 \pm 5.10^{\mathrm{abcd}}$ & $1.75 \pm 0.13^{\mathrm{defg}}$ \\
\hline 5 & 1 & 0 & $6.50 \pm 0.50^{\mathrm{a}}$ & $3.20 \pm 0.32^{\mathrm{a}}$ & $46.50 \pm 3.43^{\mathrm{a}}$ & $1.96 \pm 0.13^{\mathrm{cd}}$ \\
\hline 1 & 0 & 0.5 & $3.70 \pm 0.26^{\mathrm{fgh}}$ & $1.50 \pm 0.11^{\mathrm{fg}}$ & $17.80 \pm 1.54^{\mathrm{ij}}$ & $1.19 \pm 0.06^{\mathrm{i}}$ \\
\hline 2 & 0 & 0.5 & $4.60 \pm 0.27^{\text {bcdefg }}$ & $1.97 \pm 0.13^{\mathrm{def}}$ & $26.00 \pm 2.34^{\mathrm{fghi}}$ & $1.52 \pm 0.04^{\mathrm{fghi}}$ \\
\hline 3 & 0 & 0.5 & $4.70 \pm 0.33^{\text {bcdefg }}$ & $1.74 \pm 0.14^{\mathrm{efg}}$ & $25.70 \pm 2.82^{\text {fghi }}$ & $1.43 \pm 0.06^{\mathrm{ghi}}$ \\
\hline 4 & 0 & 0.5 & $5.50 \pm 0.56^{\mathrm{abc}}$ & $2.14 \pm 0.20^{\text {cdef }}$ & $28.30 \pm 3.09^{\text {defgh }}$ & $1.45 \pm 0.11^{\mathrm{ghi}}$ \\
\hline 5 & 0 & 0.5 & $4.60 \pm 0.76^{\text {bcdefg }}$ & $2.45 \pm 0.30^{\text {abcde }}$ & $29.90 \pm 4.09^{\text {cdefg }}$ & $1.48 \pm 0.06^{\mathrm{fghi}}$ \\
\hline 1 & 0 & 1 & $3.50 \pm 0.17^{\mathrm{gh}}$ & $1.63 \pm 0.04^{\mathrm{fg}}$ & $20.10 \pm 1.50^{\text {ghij }}$ & $1.39 \pm 0.02^{\mathrm{ghi}}$ \\
\hline 2 & 0 & 1 & $4.10 \pm 0.46^{\text {cdefg }}$ & $2.14 \pm 0.12^{\text {cdef }}$ & $27.10 \pm 1.73^{\text {efghi }}$ & $1.55 \pm 0.08^{\mathrm{efgh}}$ \\
\hline 3 & 0 & 1 & $3.90 \pm 0.38^{\mathrm{efg}}$ & $1.59 \pm 0.13^{\mathrm{fg}}$ & $18.70 \pm 2.13^{\mathrm{hij}}$ & $1.27 \pm 0.04^{\mathrm{hi}}$ \\
\hline 4 & 0 & 1 & $5.10 \pm 0.43^{\text {bcdefg }}$ & $2.19 \pm 0.20^{\text {cdef }}$ & $28.80 \pm 2.40^{\text {cdefg }}$ & $1.62 \pm 0.07^{\text {defgh }}$ \\
\hline 5 & 0 & 1 & $4.10 \pm 0.48^{\text {cdefg }}$ & $2.38 \pm 0.27^{\text {bcde }}$ & $23.10 \pm 2.00^{\text {fghi }}$ & $1.65 \pm 0.06^{\mathrm{defg}}$ \\
\hline
\end{tabular}

Means followed by same letters within each column are not significantly different at $p \leq 0.05$, according to DMRT.

Table 5: Effect of liquid medium supplemented with Kinetin, NAA, BAP and TDZ on shoot and root multiplication of G. globulifera for eight weeks.

\begin{tabular}{|c|c|c|c|c|c|c|c|}
\hline $\begin{array}{l}\text { Kinetin } \\
(\mathrm{mg} / \mathrm{l})\end{array}$ & $\begin{array}{c}\text { NAA } \\
(\mathrm{mg} / \mathrm{l})\end{array}$ & $\begin{array}{c}\text { BAP } \\
(\mathrm{mg} / \mathrm{l})\end{array}$ & $\begin{array}{c}\mathrm{TDZ} \\
(\mathrm{mg} / \mathrm{l})\end{array}$ & $\begin{array}{c}\text { Average no. of } \\
\text { shoots/explant } \\
\text { mean } \pm S E\end{array}$ & $\begin{array}{c}\text { Average shoot } \\
\text { length }(\mathrm{cm}) \\
\text { mean } \pm \mathrm{SE}\end{array}$ & $\begin{array}{c}\text { Average no. of } \\
\text { roots/explant } \\
\text { mean } \pm S E\end{array}$ & $\begin{array}{c}\text { Average root } \\
\text { length }(\mathrm{cm}) \\
\text { mean } \pm \mathrm{SE}\end{array}$ \\
\hline 0 & 0 & 0 & 0 & $3.67 \pm 0.19^{\mathrm{b}}$ & $2.25 \pm 0.19^{\mathrm{b}}$ & $12.08 \pm 1.09^{b}$ & $1.10 \pm 0.07^{b}$ \\
\hline 3 & 0.5 & 0 & 0 & $3.75 \pm 0.28^{\mathrm{b}}$ & $1.97 \pm 0.14^{\mathrm{b}}$ & $8.58 \pm 1.14^{\mathrm{b}}$ & $1.27 \pm 0.08^{\mathrm{b}}$ \\
\hline 0 & 0 & 2 & 0 & $4.92 \pm 0.45^{\mathrm{b}}$ & $2.84 \pm 0.18^{\mathrm{a}}$ & $20.92 \pm 1.54^{\mathrm{a}}$ & $1.51 \pm 0.05^{\mathrm{a}}$ \\
\hline 0 & 0 & 0 & 2 & $12.25 \pm 0.88^{\mathrm{a}}$ & $2.00 \pm 0.16^{\mathrm{b}}$ & $4.08 \pm 0.58^{\mathrm{d}}$ & $0.76 \pm 0.11^{\mathrm{c}}$ \\
\hline
\end{tabular}

Means followed by same letters within each column are not significantly different at $p \leq 0.05$, according to DMRT.

Pharmacognosy Journal, Vol 12, Issue 6(Suppl), Nov-Dec, 2020 
Plantlets (6-8 cm in height) with well-developed shoots and roots were transferred for eight weeks during the rainy season into a greenhouse at the Department of Biology, Faculty of Science, Mahasakham University, Mahasarakham, Thailand. After eight weeks, plantlets of G. globulifera transplanted into the soil, sand and soil mixed with sand produced various sizes of storage roots and new leaves. They are well adapted to the external environment and can be used as planting material. All the planting material showed $100 \%$ survival rate. The maximum number of shoots ( 4.35 shots/plant), average shoot length $(14.03 \mathrm{~cm})$ and number of leaves (31.55 leaves/plant) were observed in soil (Table 6 and Figure 3).

\section{Bioactive Compounds}

Antioxidant activity is an excellent example of how plant extracts can provide a practical gain. ${ }^{10}$ From the results of TPC, TFC and free radical scavenging activity (FRSA) of methanol extracts of ex vitro plantlets and in vitro-derived plantlets, the results specified that there is a significant difference between the extracts of different parts of the plantlets. The TPC demonstrated in gallic acid equivalents showed the highest value of $52.28 \mathrm{mg} \mathrm{GAE} / \mathrm{g}$ crude extract in the rhizome of in vitro-derived plantlets, whereas the rhizome of ex vitro plantlets showed $50.56 \mathrm{mg}$ GAE/g crude extract (Table 7). Likewise, the rhizome of the in vitroderived plantlets had the highest FRSA (93.55\%) and lowest $\mathrm{IC}_{50}(0.46$ $\mathrm{mg} / \mathrm{ml}$ ). TFC was expressed in catechin equivalents and showed the highest value of $33.62 \mathrm{mg} \mathrm{CE} / \mathrm{g}$ crude extract in the rhizome of ex vitro plantlets. The DPPH scavenging ability had higher correlations with TPC $(r=0.913)$, and less correlation with TFC $(r=0.894)$.

\section{DISCUSSION}

When the microshoots of G. globulifera were cultured on the MS medium with various concentrations of BAP or Kinetin alone, BAP plus NAA or IBA, Kinetin plus NAA or IBA added, the shoot and root formation were different. In the same genus, the BAP treatments are consistent
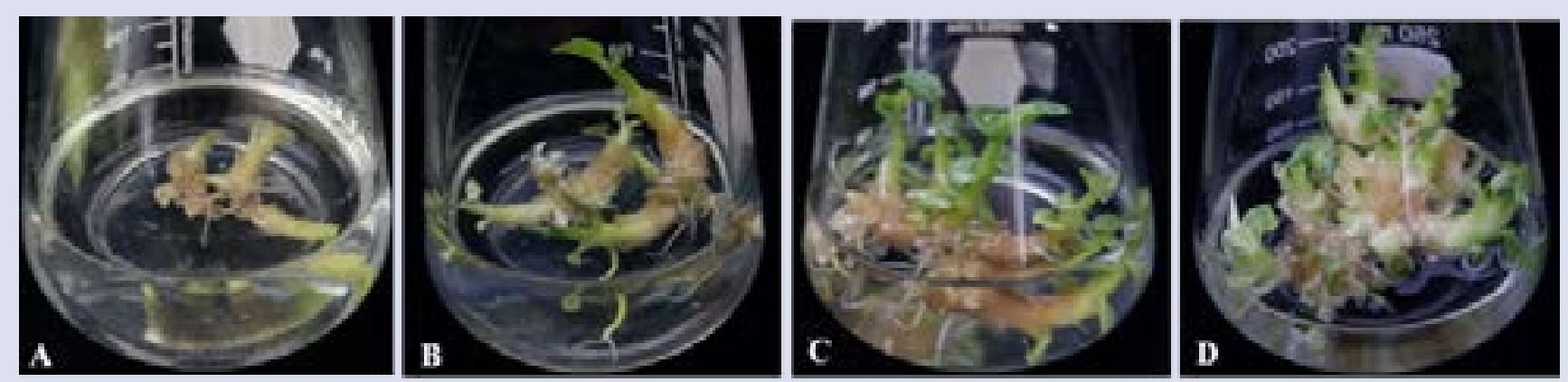

Figure 2: Multiple shoot formation of G. globulifera after eight weeks of cultivation on liquid MS medium supplemented with plant growth regulators. (A. MS (control), B. Kinetin $3 \mathrm{mg} / \mathrm{l}$ + NAA $0.5 \mathrm{mg} / \mathrm{l}$, C. BAP $2 \mathrm{mg} / \mathrm{l}$ and D. TDZ $2 \mathrm{mg} / \mathrm{l})$.
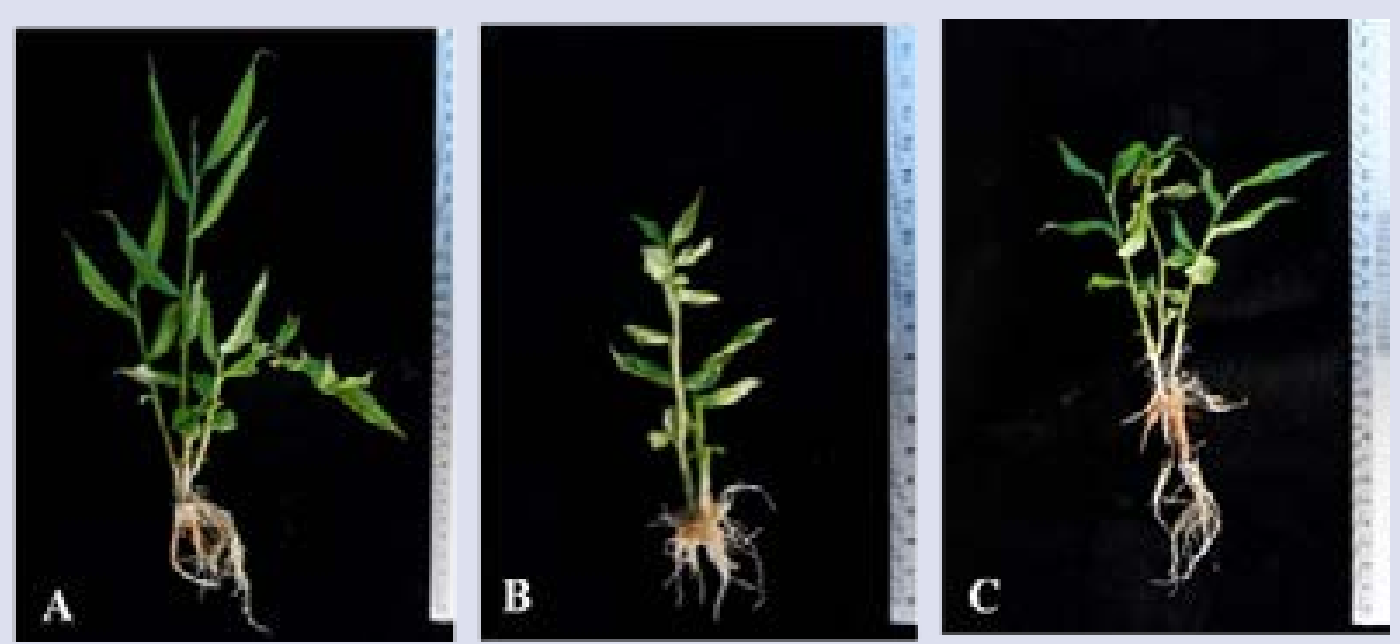

Figure 3: Acclimatized plantlets eight weeks after transfer to pots in a greenhouse. (A. soil, B. sand and C. soil:sand (1:1)).

Table 6: Effect of potting media on plantlet performance of G. globulifera after eight weeks of acclimatization.

\begin{tabular}{ccccc}
\hline Potting medium & $\begin{array}{c}\text { Average no. of } \\
\text { shoots/plant } \\
\text { mean } \pm \text { SE }\end{array}$ & $\begin{array}{c}\text { Average shoot } \\
\text { length }(\mathrm{cm}) \\
\text { mean } \pm \text { SE }\end{array}$ & $\begin{array}{c}\text { Average no. of leaves/ } \\
\text { plant } \\
\text { Mean } \pm \text { SE }\end{array}$ & Survival rate (\%) \\
\hline Soil & $4.35 \pm 0.42^{\mathrm{a}}$ & $14.03 \pm 0.51^{\mathrm{a}}$ & $31.55 \pm 2.19^{\mathrm{a}}$ & 100 \\
Sand & $2.90 \pm 0.2^{\mathrm{b}}$ & $6.27 \pm 0.37^{\mathrm{b}}$ & $14.80 \pm 1.11^{\mathrm{c}}$ & 100 \\
Soil mixed with sand & $3.55 \pm 0.27^{\mathrm{ab}}$ & $7.23 \pm 0.58^{\mathrm{b}}$ & $19.90 \pm 1.46^{\mathrm{b}}$ & 100 \\
\hline
\end{tabular}

Means followed by same letters within each column are not significantly different at $p \leq 0.05$, according to DMRT. 
Table 7: TPC, TFC, FRSA and IC ${ }_{50}$ in $80 \%$ (v/v) methanol extract of G. globulifera by ultrasonically method from different parts of explant.

\begin{tabular}{|c|c|c|c|c|c|}
\hline & & $\begin{array}{c}\text { TPC } \\
\text { (mg GAE/g crude } \\
\text { extract) } \\
\text { mean } \pm \text { SE }\end{array}$ & $\begin{array}{c}\text { TFC } \\
\text { (mg CE/g crude } \\
\text { extract) } \\
\text { mean } \pm \text { SE }\end{array}$ & $\begin{array}{c}\text { FRSA } \\
(\%) \\
\text { mean } \pm \text { SE }\end{array}$ & $\begin{array}{c}\mathrm{IC}_{50} \\
(\mathrm{mg} / \mathrm{ml}) \\
\text { mean } \pm \mathrm{SE}\end{array}$ \\
\hline \multirow{4}{*}{ Nature } & Rhizome & $50.56 \pm 0.54^{\mathrm{b}}$ & $33.62 \pm 0.32^{\mathrm{a}}$ & $92.01 \pm 0.07^{\mathrm{a}}$ & $0.47 \pm 0.002$ \\
\hline & Storage root & $33.63 \pm 0.37^{f}$ & $15.31 \pm 0.90^{\mathrm{d}}$ & $73.47 \pm 0.41^{\mathrm{c}}$ & $0.65 \pm 0.004$ \\
\hline & Leaf & $45.81 \pm 0.71^{\mathrm{c}}$ & $19.53 \pm 0.22^{\mathrm{b}}$ & $70.25 \pm 0.26^{\mathrm{d}}$ & $0.67 \pm 0.001^{\mathrm{c}}$ \\
\hline & Pseudostems & $20.75 \pm 0.26^{\mathrm{g}}$ & $5.61 \pm 0.59^{\mathrm{e}}$ & $37.59 \pm 0.42^{\mathrm{f}}$ & $1.31 \pm 0.002^{\mathrm{a}}$ \\
\hline \multirow{4}{*}{$\begin{array}{l}\text { In vitro-derived } \\
\text { plantlets }\end{array}$} & Rhizome & $52.28 \pm 0.41^{\mathrm{a}}$ & $32.20 \pm 0.77^{\mathrm{a}}$ & $93.55 \pm 0.18^{\mathrm{a}}$ & $0.46 \pm 0.002$ \\
\hline & Storage root & $39.91 \pm 0.60^{d}$ & $17.39 \pm 0.52^{c}$ & $87.48 \pm 0.16^{b}$ & $0.52 \pm 0.003^{e}$ \\
\hline & Leaf & $36.56 \pm 0.14^{\mathrm{e}}$ & $15.53 \pm 0.13^{\mathrm{d}}$ & $59.32 \pm 1.72^{\mathrm{e}}$ & $0.81 \pm 0.015$ \\
\hline & Pseudostems & $21.93 \pm 0.17^{g}$ & $6.87 \pm 0.26^{\mathrm{e}}$ & $38.42 \pm 0.43^{\mathrm{f}}$ & $1.28 \pm 0.007^{b}$ \\
\hline
\end{tabular}

Means followed by same letters within each column are not significantly different at $p \leq 0.05$, according to DMRT.

with Kho et al. ${ }^{11}$ who reported the medium supplement with $3 \mathrm{mg} / \mathrm{l}$ of BAP showed the highest number of shoots (6.60 shoots/explant) when culturing G. brachyanthera. Nevertheless, these results differed from those of Chuengpanya et al. ${ }^{4}$ who reported that the maximum number of shoots was 24.1 shoots/explant and 180.4 roots/explant when culturing G. siamensis on MS medium containing $2.0 \mathrm{mg} / \mathrm{l}$ of BAP. Saensouk et $a l .{ }^{5}$ reported different results, the MS medium supplemented with 3.0 $\mathrm{mg} / \mathrm{l}$ of BAP show the number of shoots was 3.80 shoots/explant of $G$. schomberkii. Then, $5 \mathrm{mg} / \mathrm{l}$ of Kinetin showed the best response on shoot and root induction. These results are different from Parida et al. ${ }^{12}$ who reported the maximum number of shoots was 5.8 shoots/explant when culturing G. marantina on a medium that contained $3 \mathrm{mg} / \mathrm{l}$ Kinetin. The result of comparing different plant growth regulators on liquid media showed the differences from Saensouk et al. ${ }^{5}$ who reported in vitro propagation of $G$. schomburgkii on MS medium supplemented with $2.00 \mathrm{mg} / \mathrm{l}$ of TDZ (9.10 shoots/explant).

A culture medium was supplemented with cytokinins (BAP, Kinetin and TDZ) displayed a strong effect on the proliferation rate of the micropropagation process. In general, BAP, Kinetin and TDZ hormones have been the most commonly used media and plant growth regulators in plant micropropagation. Cytokinin also mediates the responses to irrelevant factors, such as light conditions in the shoot and accessibility of nutrients and water in the root. ${ }^{13}$ BAP could increase the level of cytokinin in plants, protects the pith tissue and prolongs the active photosynthetic duration and improves the photosynthetic efficiency factors. ${ }^{14}$ Kinetin could maintain the stability of chlorophyll and enhances the activities of antioxidant enzymes. ${ }^{15} \mathrm{TDZ}$ could be an effective bioregulator in plant tissue cultures in a wide array of plant species. ${ }^{16}$

In the present study, it was found that using a plant growth regulator combination (BAP plus NAA or IBA and Kinetin plus NAA or IBA) could induce shoot formation in similar amounts. The results show the best shoot and root induction occurred on the medium supplement with BAP plus NAA or IBA. These results are different from Parida et al. ${ }^{12}$ who studied the effect of combinations of plant grow regulators. MS medium supplement with $3 \mathrm{mg} / \mathrm{l}$ of BAP plus $0.5 \mathrm{mg} / \mathrm{l}$ of NAA showed the best number of shoots (6.5 shoots/explant). The effect of Kinetin in combination with NAA or IBA demonstrated an increase in the number of plantlets as well. In the same family, these results are consistent with Nguyen et al. ${ }^{17}$ who reported a medium supplement with $1 \mathrm{mg} / \mathrm{l}$ of Kinetin plus $0.5 \mathrm{mg} / \mathrm{l}$ of NAA have the highest number of shoots (5.10 shoots/explant) and best shoot length $(6.43 \mathrm{~cm})$. However, root induction was effective when using a combination of cytokinin and auxin. NAA is a plant growth regulator in the auxin group and is used for plant tissue culture. It is also a rooting agent and used for vegetative propagation of plants from stem and leaf explants. ${ }^{18}$ The number of shoots per explant induced depended on the ratio of cytokinin and auxin used for shoot multiplication. Cytokinin is responsible for the regulation of plant growth through an influence on the number or duration of cell division cycles in the root and shoot meristems. ${ }^{19}$ Auxins play a major role in root development, apical dominance and plant senescence, and is associated with cell expansion, cell division and cell differentiation. ${ }^{20}$

In the present study, in vitro plantlets derived using the tissue culture technique produced new shoots, roots and leaves. The plantlet was healthy and morphologically like the mother plants after being transferred to the field. These results differ from those of Saensouk et al. ${ }^{5}$ who reported that when the plantlets of G. schomburgkii were transferred to pots containing sand they showed the highest percentage of surviving plantlets (80\%), average number of leaves per shoot (21.62) and average shoot length $(15.00 \mathrm{~cm})$. In this study, in vitro plantlets derived from tissue culture techniques produced healthy and plants morphologically similar to the mother after being transferred to the field.

Plants contain a wide range of bioactive compounds with essential health and food applications. Among these compounds, a strong correlation was observed between antioxidant activity and the total plant phenolic content, indicating that phenolic compounds may be the main contributor to their antioxidant ability. ${ }^{21}$ The characterization of the phytochemical contents of different tissues of G. globulifera is critical to establishing its medicinal importance. The total phenol and flavonoid contents of in vitro-derived plantlets for one year and natural conditions are the rhizomes, storage root, leaves and pseudostems. In this study, it was demonstrated that in vitro-derived plantlets had higher levels of phenolic and antioxidant activities than those in natural plantlets. This is consistent with Shohael et al. ${ }^{22}$ who reported that in vitro conditions enhanced the secondary production of metabolites through the modulation of primary plant metabolism. The rate of synthesis and gene expression of secondary metabolites may be significantly affected by the nutritional content and plant hormones used in the in vitro culture. ${ }^{23}$

\section{CONCLUSION}

In conclusion, a wide-ranging investigation into in vitro propagation by shoot proliferation, measurement of the total phenolic contents, total flavonoid contents and the free radical scavenging activity (FRSA) analysis, was conducted. Consequently, the present research will contribute to commercial production and pharmaceutically significant conservation. The determination of the free radical scavenging potential of methanol extracts from G. globulifera can be used for therapeutic benefits. This study presents the first report of shoot multiplication, acclimatization, total phenolic contents, total flavonoid contents and 
antioxidant activity of G. globulifera. This significant study could be useful for propagating G. globulifera at a commercial scale, as well as for genetic improvement of this valuable plant in the future.

\section{ACKNOWLEDGEMENTS}

The authors would like to thank the Department of Biology, Faculty of Science, Mahasarakham University for their facilities during the research. Also, thanks to Dr. Jolyon Dodgson for language editing and suggestions to improve the manuscript. This research was financially supported by the Faculty of Science, Mahasarakham University (Grant year 2020).

\section{REFERENCES}

1. Aslam MS, Ahmad MS. Ethno botanical uses of Globba species: a brief review. BAOJ Pharm. 2017;3(2):1-7.

2. Murashige T, Skoog F. A revised medium for rapid growth and bioassay tobacco tissue culture. J Plant Physiol. 1962;15:473-97.

3. Parida R, Mohanty S, Nayak S. In vitro plant regeneration potential of genetically stable Globba marantina L., Zingiberaceous species and its conservation. Proceedings of the National Academy of Sciences India Section B - Biological Sciences. 2018;88(1):321-27.

4. Chuengpanya R, Chuenboonngarm N, Jenjittikul T, Thammasiri K, Umpunjun P, Muangkroot A. Effects of N6-benzyladenine on micropropagation of Globba williamsiana 'Dok Khao.' The $9^{\text {th }}$ Botanical Conference of Thailand, 2015. p. 1-13.

5. Saensouk P, Saensouk S, Pimmuen P. In vitro propagation of Globba schomburgkii Hook. f. via bulbil explants. Walailak J Sci \& Tech. 2018;15(10):701 10.

6. An K, Zhao D, Wang Z, Wu J, Xu Y, Xiao G. Comparison of different drying methods on Chinese ginger (Zingiber officinale Roscoe): Changes in volatiles, chemical profile, antioxidant properties, and microstructure. Food Chem. 2016;197:1292-300.

7. Lister E, Wilson P. Measurement of total phenolics and ABTS assay for antioxidant activity (personal communication). Lincoln, New Zealand: Crop Research Institute; 2001.

8. Zhishen J, Mengcheng T, Jianming W. The determination of flavonoid contents in mulberry and their scavenging effects on superoxide radicals. Food Chem. 1999:64(4):555-9.

9. Yen GC, Hsieh CL. Antioxidant effects of dopamine and related compounds. Biosci Biotechnol Biochem. 1997;61(10):1646-9.
10. Angerhofer CK, Maes D, Giacomoni PU. The use of natural compounds and botanicals in the development of anti-aging skin care products. Skin Aging Handbook. 2009:205-63.

11. Kho PE, Sani HB, Boyce PC, Sim SL. In vitro propagation of Globba brachyanthera K.Schum. Asia Pac J Mol Biol Biotechnol. 2010;18(1):117-20.

12. Parida R, Mohanty S, Nayak S. In vitro plant regeneration potential of genetically stable Globba marantina L., Zingiberaceous species and its conservation. Proceedings of the National Academy of Sciences India Section B - Online J Biol Sci. 2018;88(1):321-27.

13. Werner T, Schmülling T. Cytokinin action in plant development. Curr Opin Plant Biol. 2009;12(5):527-8.

14. Ren B, Zhu Y, Zhang J, Dong S, Liu P, Zhao B. Effects of spraying exogenous hormone 6-benzyladenine (6-BA) after waterlogging on grain yield and growth of summer maize. Field Crops Res. 2016;188:96-104.

15. Wang Y, Wang J, Shi B, Yu T, Qi J, Meyerowitz EM, Jiao Y. The stem cell niche in leaf axils is established by auxin and cytokinin in Arabidopsis. Plant Cell. 2014;26(5):2055-67.

16. Guo B, Abbasi BH, Zeb A, Xu LL, WeiYH. Thidiazuron: a multi-dimensional plant growth regulator Afr J Biotechnol. 2011;10(45):8984-9000.

17. Nguyen HL, Doan TD, Tae HK, Moon SY. Micropropagation of zedoary (Curcuma zedoaria Roscoe) - A valuable medicinal plant. Plant Cell Tiss Org Cult. 2005;81(1):119-22.

18. Khandaker MM, Md Rasdi MZ, Naeimah NN, Mat N. Effects of naphthalene acetic acid (NAA) on the plant growth and sugars effects on the cut flowers mokara chark kuan orchid. Bioscience. 2017;33(1):19-30.

19. Werner T, Motyka $V$, Strnad M, Schmülling T. Regulation of plant growth by cytokinin. Proc Natl Acad Sci U.S.A. 2001;98(18):10487-92.

20. Vadassery J, Ritter C, Venus Y, Camehl I, Varma A, Shahollari B, et al. The role of auxins and cytokinins in the mutualistic interaction between Arabidopsis and Piriformospora indica. Mol Plant Microbe Interact. 2008;21(10):1371-83.

21. Martins S, Mussatto SI, Martínez-Avila G, Montañez-Saenz J, Aguilar CN Teixeira JA. Bioactive phenolic compounds: production and extraction by solidstate fermentation. A Review Biotechnol Adv. 2011;29(3):365-73.

22. Shohael AM, Ali MB, Yu KW, Hahn EJ, Islam R, Paek KY. Effect of light on oxidative stress, secondary metabolites, and induction of antioxidant enzymes in Eleutherococcus senticosus somatic embryos in bioreactor. Process Biochem. 2006;41(5):1179-85.

23. Manivannan A, Soundararajan $P$, Park $Y G$, Jeong BR. In vitro propagation phytochemical analysis, and evaluation of free radical scavenging property of Scrophularia kakudensis Franch tissue extracts. Biomed Res Int. 2015:1-11. 


\section{GRAPHICAL ABSTRACT}

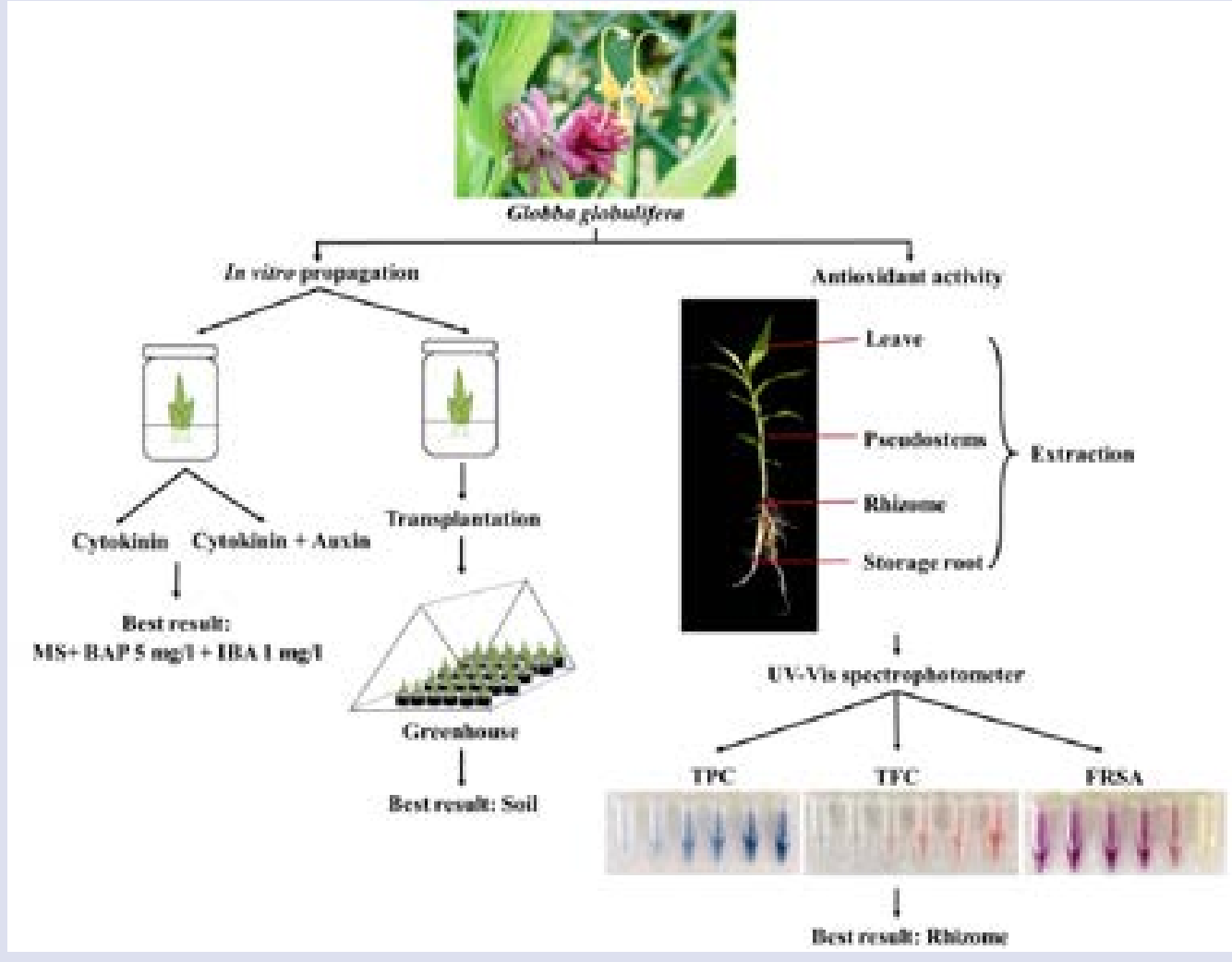

\section{ABOUT AUTHORS}

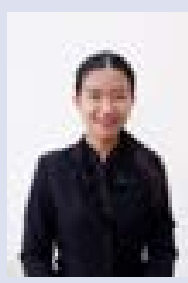

Wipa Yaowachai is a student studying for a M.Sc. degree in Biology at Department of Biology, Faculty of Science, Mahasarakham University, Thailand. Her research projects focus on Plant Tissue Culture, Plant extraction and Bioactive compounds.

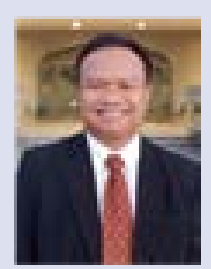

Surapon Saensouk is an Associate Professor and lecturer at Walairukhavej Botanical Research Institute, Mahasarakham University, Thailand. His research projects focus on Plant Taxonomy, Biodiversity, Chromosome, Pollen, Plant Anatomy, Plant Geography and Ethnobotany.

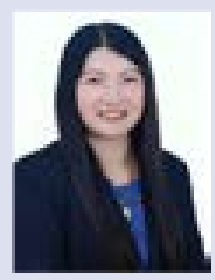

Piyaporn Saensouk is an Assistant Professor and lecturer at Department of Biology, Faculty of Science, Mahasarakham University, Thailand. Her research projects focus on Plant Tissue Culture, Plant Anatomy, Palynology and Plant Chromosome.

Cite this article: Yaowachai W, Saensouk S, Saensouk P. In Vitro Propagation and Determination of Total Phenolic Compounds, Flavonoid Contents and Antioxidative Activity of Globba globulifera Gagnep. Pharmacogn J. 2020;12(6)Suppl:1740-7. 